\title{
PENGARUH PENERAPAN GOOD CORPORATE GOVERNANCE, OPINION SHOPPING, KUALITAS AUDIT, DAN AUDIT CLIENT TENURE TERHADAP PENERIMAAN OPINI AUDIT GOING CONCERN AUDITING
}

\author{
Panggah Wira Angkasa, Dewi Indriasih, dan Baihaqi Fanani \\ Fakultas Ekonomi dan Bisnis Universitas Pancasakti
}

\begin{abstract}
The Impact of Good Governance, Opinion Shopping, Quality Audit and Audit Client Tenure Application towards Going Concern Opinion Audit Acceptance (Empirical Studies on Infrastructure Services Company, Utility, and Transportation which Registered at Indonesian Stock Exchange (ISE) during 2013 - 2017 Period). Essay. Tegal: Economic \& Business Faculty, Pancasakti University Tegal. 2018. The aim of this research is to finding out the impact of institutional ownership, independent commissioner, committee audit, opinion shopping, quality audit, audit client tenure towards going concern's opinion audit on infrastructure services company, utility, and transportation which registered at ISE during $2013-2017$ period. The population in this research are infrastructure services company, utility, and transportation which registered at ISE during 2013 - 2017 period and the sample determination by using purposive sampling method, so within the result obtained 15 company's samples. The data analysis method used is logistic regression analysis. Based on logistic regression analytic, the research result concluded that institutional ownership $(0,109)$, audit committee $(0,429)$, opinion shopping $(0,607)$, and quality audit $(0,998)$ are not affecting the going concern opinion audit. Meanwhile, the independent commissioner $(0,006)$, and audit client tenure $(0,004)$ are affecting the going concern opinion audit.
\end{abstract}

Keywords: going concern, opinion audit, institutional ownership, independent commissioner, committee audit, opinion shopping, quality audit, audit client tenure

\section{A. PENDAHULUAN}

Suharjono (2014) mengatakan auditor memiliki peranan penting dalam menjembatani pihak yang memerlukan laporan keuangan dan pihak perusahaan sebagai penyedia laporan keuangan. Auditor independen diperlukan untuk meminimalisasi asimetri informasi antara pihak prinsipal (pemilik perusahaan) dan agen (manajemen perusahaan) dalam mengelola aset perusahaan. Oleh karena itu auditor yang berkualitas akan bersikap independen sehingga hasil dari mengawasi kinerja manajemen bisa menjadi obyektif dan transparan (Krissindiastuti dan Rasmini, 2016). Kepercayaan pemakai laporan keuangan akan bertambah jika laporan keuangan yang telah diaudit mendapat pernyataan wajar tanpa pengecualian karena dapat mencerminkan kondisi keuangan perusahaan yang baik (Adityaningrum, 2012). Opini audit going concern memiliki dampak negatif bagi perusahaan seperti turunnya harga saham karena ketidak percayaan 
investor untuk berinvestasi dan sulit mencari modal (Yuridiskasari dan Rahmatika, 2017).

Auditor tidak dapat memprediksi peristiwa atau kondisi di masa depan, hal ini perlu dicermati oleh pemakai laporan keuangan yang awam dengan Standar Profesional Akuntan Publik (SPAP) karena sering menganggap bahwa auditor melakukan kegagalan dalam memberikan peringatan, sebagaian besar masyarakat menganggap bahwa pendapat wajar tanpa pengecualian merupakan jaminan bahwa perusahaan yang diaudit telah bebas dari kegagalan bisnis, jika tidak akuntan publik dianggap keliru dalam melakukan pekerjaannya (Purba, 2016:31). Oleh sebab itu ketiadaan pengacuan terhadap ketidakpastian kelangsungan usaha dalam laporan auditor tidak bisa dijadikan sebagai jaminan atas kemampuan entitas untuk mempertahankan kelangsungan usahanya.

Banyak auditor yang mengalami dilema terhadap moral dan etika profesi untuk memberikan opini audit going concern karena sulit memprediksi kelangsungan hidup perusahaan. Menurut Joanna H.Lo, 1994 (dalam Debby dan Made, 2016) mengatakan sulitnya auditor memberikan opini audit going concern karena tidak adanya prosedur penetapan status going concern yang terstruktur pada perusahaan yang bermasalah. Kesalahan dalam memberi opini juga dapat disebabkan oleh tekanan pihak manajemen. Masalah lainnya adalah selffulfilling prophecy, akuntan publik dikhawatirkan memperburuk citra perusahaan dan menimbulkan pesimisme terhadap pembaca laporan keuangan sehingga aduitor akan lebih berhati-hati untuk memberikan opini audit going concern sebab jika auditor salah dalam memprediksi kelangsungan hidup perusahaan maka yang terjadi adalah akan mempercepat kebangkrutan sebuah perusahaan karena investor membatalkan investasinya dan kreditor akan menarik dananya (Sasmita, dkk., 2015).

Berdasarkan ulasan tersebut, maka rumusan masalah dalam penelitian sebagai berikut: Apakah ada pengaruh kepemilikan institusional, komisaris independen, komite audit, opinion shopping, kualitas audit dan audit client tenure terhadap penerimaan opini audit going cocnern.

Tujuan dari penelitian ini adalah untuk mengetahui apakah ada pengaruh kepemilikan institusional, komisaris independen, komite audit, opinion shopping, kualitas audit dan audit client tenure terhadap penerimaan opini audit going cocnern.

\section{B. KEREANGKAN PEMIKIRAN DAN HIPOTESIS}

\section{Pengaruh Kepemilikan Institusional Terhadap Opini Audit Going Concern}

Adanya kepemilikan oleh institusional dapat mendorong peningkatan pengawasan yang lebih optimal. Pengawasan tersebut dapat menjamin manajer bertindak sesuai dengan kepentingan pemilik perusahaan dan bukan hanya untuk kepentingan dirinya sendiri (Hary, 2017:41). Semakin tinggi kepemilikan saham oleh perusahaan dapat meningkatkan nilai perusahan sehingga mengurangi resiko kesulitan keuangan dan dapat mengurangi potensi kebangkrutan. Pernyataan diatas sejalan dengan penelitian yang dilakukan oleh Eduk dan 
Nugraeni (2015) dan Nurdin, dkk., (2016) yang menyatakan kepemilikan institusional berpengaruh terhadap opini audit going concern.

H1 : Kepemilikan Institusional diduga berpengaruh terhadap penerimaan opini audit going concern.

\section{Pengaruh Komisaris Independen Terhadap Opini Audit Going Concern.}

Salah satu yang menyebabkan permasalahan timbul di dalam perusahaan dikarenakan adanya perbedaan kepentingan antara manajemen dan pemilik perusahaan, sehingga dibutuhkan pengawasan oleh pihak independen yaitu komisaris independen agar manajemen bertindak sesuai keinginan pemegang saham mayoritas maupun pemegang saham minoritas dan tidak melakukan tindakan kecurangan yang dapat merugikan pemilik (Adjani dan Rahardja, 2013). Keberadaan komisaris independen dalam perusahaan diharapkan mampu menjamin transparansi laporan keuangan perusahaan serta mengawasi kepatuhan perusahaan terhadap peraturan yang berlaku. Sehingga semakin besar proporsi komisaris independen mampu mengurangi kemungkinan pemberian opini audit going concern. Teori di atas mendukung penelitian yang dilakukan oleh Eduk dan Nugraeni (2015), dan Sigitson (2016), dan Rabiah (2015) yang menyimpulkan bahwa komisaris independen berpengaruh tehadap opini audit going concern.

H2 : Komisaris Independen diduga berpengaruh terhadap penerimaan opini audit going concern.

\section{Pengaruh Komite Audit Terhadap Penerimaan Opini Audit Going Concern.}

Nuresa dan Hadiprajitno (2013) mengatakan komite audit dapat memberikan kontribusi bagi pengembangan manajemen strategis dan diharapkan mampu memberikan rekomendasi untuk dewan dengan melihat setiap permasalahan keuangan dan operasional peruasahaan. Anggota komite audit dengan latar belakang dibidang akuntansi dan keuangan akan lebih efektif mengawasi pelaporan keuangan dan memberikan kualitas laporan keuangan yang baik. Sehingga semakin besar proporsi komite audit berlatar belakang akuntansi dan keuangan maka semakin kecil kemungkinan pemberian opini audit terkait masalah kelangsungan hidup suatu perusahaan kedepannya. Hasil penelitian oleh Rabiah (2015) yang sesuai dengan teori diatas yang menyatakan bahwa terdapat pengaruh antara komite audit dengan opini audit going concern.

H3 : Komite Audit diduga berpengaruh terhadap penerimaan opini audit going concern.

\section{Pengaruh Opinion Shopping Ter- hadap Penerimaan Opini Audit Going Concern.}

Perilaku opinion shopping dilakukan oleh manajer untuk manipulasi pelaporan keuangan agar auditor memberikan opini unqualified dengan cara memberi tekanan kepada auditor. Tekanan yang dimaksud adalah perusahaan mengancam akan melakukan pergantian auditor dengan mencari auditor baru yang bersedia mengikuti manajemen mengenai perlakuan pelaporan 
akuntansi (Kussumayanti dan Widhiyani, 2017).

Semakin sering perusahaan melakukan praktik opinion shopping untuk mendapatkan opini audit non going concern maka sebenarnya perusahaan sedang menjerumuskan dirinya sendiri dengan menimbulkan permasalahan baru yang berujung kebangkrutan. Reputasi auditor juga akan menjadi hancur jika terbukti tidak independen. Jika perusahaan berhasil melakukan opinion shopping maka kemungkinan perusahaan mendapatkan opini audit going concern semakin kecil. Hasil penelitian yang dilakukan oleh Kusumayanti dan Widhiyani (2017), Yudhanto dan Mutmainah (2012), Nursasi dan Maria (2015) yang menyatakan bahwa opinion shopping berpengaruh terhadap opini audit going concern.

H4: Opinion Shopping diduga berpengaruh terhadap penerimaan opini audit going concern.

\section{Pengaruh Kualitas Audit Terhadap Penerimaan Opini Audit Going Concern.}

Menurut Caswell et al. (1995) (dalam Krissindiastuti dan Rasmini 2016) menyatakan klien beranggapan bahwa auditor dari KAP yang besar dan memiliki afiliasai dengan KAP internasional memiliki kualitas audit yang lebih tinggi. Kantor Akuntan Publik berskala besar akan cenderung mengeluarkan opini audit going concern karena besikap independen jika terdapat masalah going concern pada klien (Elviona, 2017). Pengungkapan masalah going concern pada perusahaan membutuhkan kecermatan dan ketepatan, oleh karena itu perlu adanya kemampuan dan pengalaman yang sangat tinggi. Penjelasan tersebut mendukung penelitian Difa dan Suryono (2015) serta Tandungan dan Mertha (2016) yang menyatakan hasil dari penelitian kualitas audit berpengaruh terhadap opini audit going concern.

H5 : Kualitas Audit diduga berpengaruh terhadap penerimaan opini audit going concern.

\section{Pengaruh Audit Client Tenure ter- hadap Opini Audit Going Concern.}

Lamanya hubungan auditor dengan klien menjadikan auditor kehilangan independensinya sehingga untuk memberikan opini going concern akan sulit dilakukan karena auditor menjaga hubungan baik dengan klien. Ketika hubungan antara auditor dengan klien telah berlangsung bertahun-tahun auditor memandang klien sebagai sumber penghasilan yang potensial, sehingga dapat mengurangi independensi KAP (Widyantari,2011). Dengan begitu semakin lama perusahaan melakukan perikatan dengan klien maka auditor semakin tidak independen dan kecil kemungkinan perusahaan mendapan opini audit going cocnern. Teori di atas dan sejalan dengan penelitian yang dilakukan oleh Krissindiastuti dan Rasmini (2016), Nursasi dan Maria (2015), yang menemukan hasil bahwa audit client tenure berpengaruh terhadap opini audit going concern.

H6 : Audit Client Tenure diduga berpengaruh terhadap penerimaan opini audit going concern.

Dari uraian diatas, peneliti mengambil kesimpulan bahwa 
Kerangka Konseptual

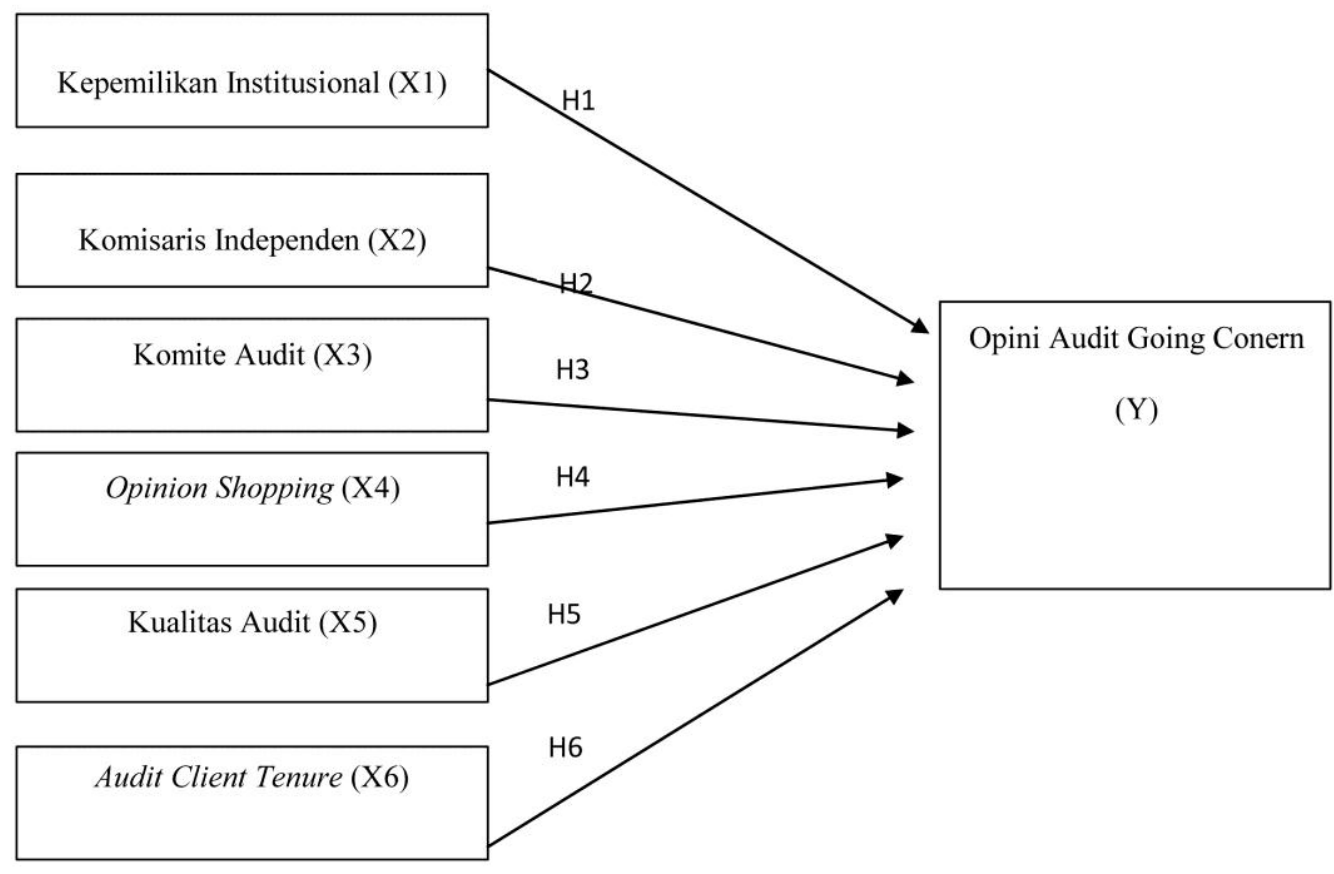

\section{METODE PENELITIAN}

Metode yang diterapkan dalam penelitian ini adalah kuantitatif, yaitu penelitian di mana data yang dibutuhkan dalam penelitian berupa bilangan atau angka. Metode pemilihan data yang digunakan dalam penelitian ini adalah menggunakan data sekunder, data yang diambil dari Bursa Efek Indonesia (BEI) melalui www.idx.co.id.

Data sekunder merupakan data yang mengacu kepada informasi yang telah dikumpulkan oleh seseorang, dan bukan peneliti yang melakukan studi mutakhir (Sekaran, 2006:65). Dalam penelitian ini, populasinya adalah seluruh perusahaan sektor Infrastruktur, Utilitas, dan Transportasi yang terdaftar di Burse Efek Indonesia (BEI) pada tahun 2013-2017 sebanyak 63 perusahaan.

Teknik pengambilan sampel untuk penelitian ini menggunakan purposive sampling method, yang merupakan teknik pengambilan sampel dengan berdasarkan kriteria-kriteria yang telah ditentukan, sehingga di- peroleh 15 perusahaan dengan pengamatan 5 tahun.

\section{Opini Audit Going Concern}

Variabel dependen dalam penelitian ini adalah opini audit going concern. Opini audit going concern merupakan opini audit modifikasi karena adanya ketidakpastian perusahaan akan kelangsungan hidupya.

Variabel opini audit going concern diukur menggunakan variabel dummy. Dimana kategori 1 untuk perusahaan sektor Infrastruktur, Utilitas, dan Transportasi yang menerima opini audit going concern dan 0 untuk perusahaan Infrastruktur, Utilitas, dan Transportasi yang tidak menerima opini audit going concern. Opini audit going concern dalam penelitian ini terdapat pada opini wajar tanpa pengecualian dengan bahasa penjelas (unqualified opinion with explanatory language) yang merujuk kepada keraguan kelangsungan hidup perusahaan, opini wajar dengan pengecualian (qualified opinion), opini tidak wajar (adverse opinion), dan tidak memberikan 
pendapat (disclaimair opinion) (Difa, 2015).

\section{Kepemilikan Institusional}

Variabel ini menggambarkan tingkat kepemilikan saham oleh institusional dalam perusahaan, yang termasuk institusional antara lain perusahaan investasi, perusahaan asuransi, bank, dan perusahaan lainnya (Tarmizi dan Agnes, 2016). Menurut Nurdin, dkk., (2016) alat ukur variabel kepemilikan institusional dapat dihitung menggunakan rumus sebagai berikut:

\section{Komisaris Independen}

Berdasarkan pedoman umum good corporate governance yang dikeluarkan oleh KNKG 2006, komisaris independen merupakan anggota dewan komisaris yang tidak terafiliasi dengan pemegang saham pengendali, direksi, serta dewan komisaris lainnya, bebas dari hubungan bisnis dan kekeluargaan yang dapat mempengaruhi kemampuannya untuk bertindak independen. Rumus variabel ini adalah:

\section{$\longrightarrow \quad \times 100 \%$}

\section{Komite Audit}

Komite audit merupakan komite yang dibentuk oleh dewan komisaris untuk melakukan tugas pengawasan pengelolaan perusahaan. Keahlian akuntansi dan keuangan dapat dilihat dari latar belakang pendidikan akuntansi, memiliki sertifikasi di bidang akuntansi, atau pengalaman kerja di bidang akuntansi dan keuangan (Artawijaya dan Putri, 2016). Diukur dengan rumus sebagai berikut:

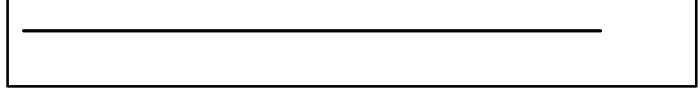

\section{Opinion Shopping}

Opinion shopping merupakan aktivitas mencari auditor yang mau mendukung perlakuan akuntansi yang diajukan pihak manajemen untuk mendukung tujuan pelaporan perusahaan. variabel ini diukur menggunakan variabel dummy dengan ketentuan sebagai berikut, angka 1 untuk perusahaan yang diaudit oleh auditor berbeda setelah mendapat opini audit going concern, dan angka 0 untuk perusahaan yang diaudit oleh auditor yang sama setelah perusahaan mendapat opini audit going concern (Kusumayanti \& Widhiyani, 2017).

\section{Kualitas Audit}

Variabel ini menggunakan variabel dummy dimana kode 1 diberikan untuk perusahaan yang menggunakan jasa KAP big four atau yang berafiliasi dengan KAP big four, sedangkan kode 0 untuk perusahaan yang menggunakan jasa KAP non big four (Mustika, 2017).

\section{Audit Client Tenure}

Audit client tenure merupakan jangka waktu perikatan yang terjalin antara Kantor Akuntan Publik terhadap auditee yang sama. Variabel ini menggunakan skala interval disesuaikan dengan lamanya hubungan KAP dengan klien. Tahun pertama perikatan dimulai dengan angka 1 dan ditambah dengan satu untuk tahun berikutnya (Krissisdiastuti dan Rasmini, 2016).

\section{Metode Analisis Data}

Pengujian hipotesis dalam penelitian ini menggunakan analisis multivariate dengan menggunakan regresi logistik (logistic regresion) karena 
variabel dependennya menggunakan dummy dan variabel independen yang ada dalam penelitian ini merupakan kombinasi antara metric dan non metric (nominal).

OA going concern $=\alpha+\beta \mathrm{NS}+\beta 2 \mathrm{~N}+\beta 3 \mathrm{OM}+\beta 4 \mathrm{OS}+\beta 5 \mathrm{REP} \mathrm{AP}+\beta 6 \mathrm{EN}+$

Keterangan:

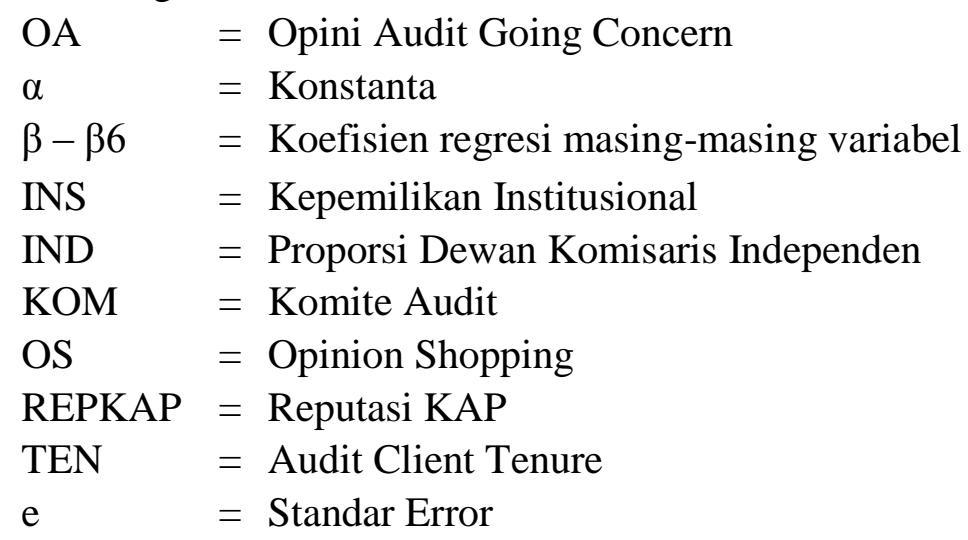

\section{HASIL}

\section{Statistik Deskriptive}

Statistik Deskriptive adalah memberikan gambaran suatu data yang dilihat dari nilai rata-rata (mean), maksimum, minimum, sum, range, standar deviasi, kurtosis dan skewness (kemencengan distribusi) (Ghozali, 2016:19). Berdasarkan data olahan SPSS versi 22 yang meliputi variabel independen kepemilikan institusional, komisaris independen, komite audit, dan audit client tenure maka akan dapat diketahui nilai maksimum, minimum, rata-rata (mean) dan standar deviasi dari tiap-tiap variabel.

Sedangkan variabel independen lain seperti opinion shopping, kualitas
Persamaan model regresi logistik yang digunakan dalam penelitian ini dapat dirumuskan sebagai berikut: audit, dan variabel dependen yaitu opini audit going concern tidak diikutsertakan dalam perhitungan statistik deskriptif karena variabel-variabel tersebut diukur dengan menggunakan skala nominal. Angka ini hanya berfungsi sebagai label kategori semata tanpa nilai intrinsik, oleh karena itu tidak tepat bila menghitung nilai rata-rata (mean) dan standar deviasi variabel tersebut (Tandungan dan Mertha, 2016). Skala nominal merupakan skala pengukuran yang menyatakan kategori atau kelompok dari suatu subyek (Ghozali, 2016:3). 
Tabel 4.2

Statistik Deskriptif

\begin{tabular}{|c|c|c|c|c|c|}
\hline & & Descripti & e Statistics & & \\
\hline & $\mathrm{N}$ & Minimum & Maximum & Mean & Std. Deviation \\
\hline kepemilikan institusional & 75 & 36,77 & 89,26 & 73,4068 & 12,08409 \\
\hline komisaris independen & 75 & 25 & ,75 & 4292 & 10278 \\
\hline komite audit & 75 & 20,00 & 100,00 & 75,0800 & 23,87397 \\
\hline audit client tenure & 75 & 1,00 & 6,00 & 3,2400 & 1,59255 \\
\hline Valid N (listwise) & 75 & & & & \\
\hline
\end{tabular}

Sumber: output SPSS, data diolah 2018

Sedangkan untuk menunjukkan hasil uji deskriptif variabel independen dan variabel dependen yang menggunakan variabel dummy yakni opinion shopping, kualitas audit, dan opini audit going concern dapat dilihat pada tabel frekuensi berikut:

Tabel 4.3

Hasil Uji Deskriptif Opinion Shopping

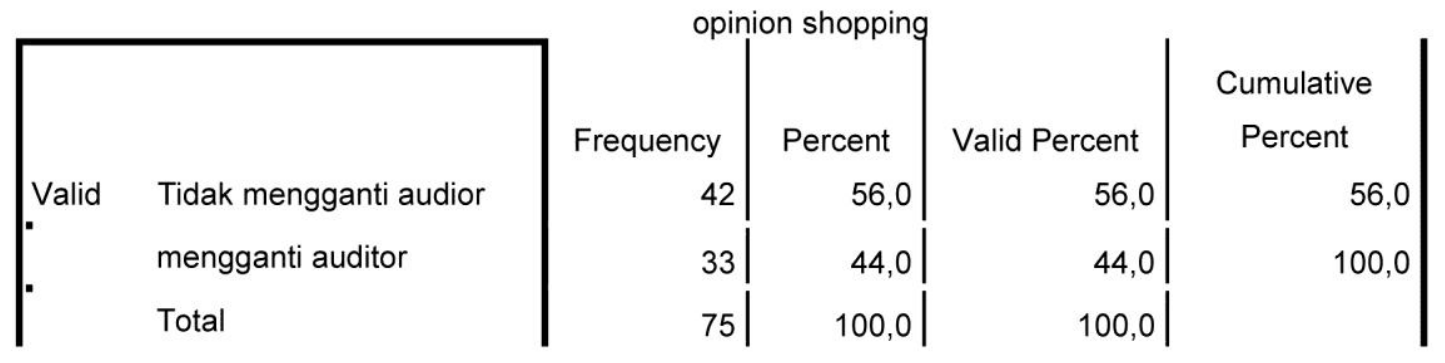

Sumber: output SPSS, data diolah 2018

Tabel 4.4

Hasil Uji Deskriptif Kualitas Audit
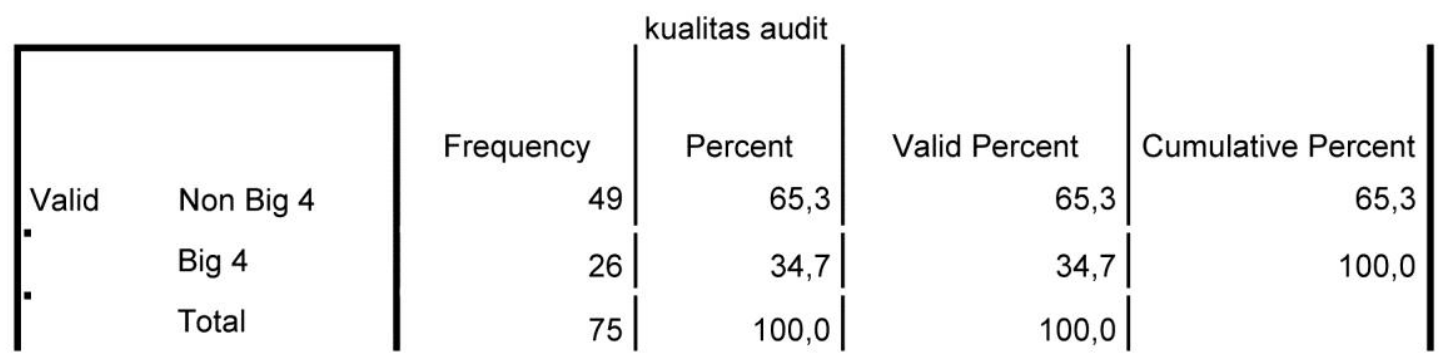

Sumber: output SPSS, data diolah 2018 
Tabel 4.5

Hasil Uji Deskriptif Opini Audit Going Concern

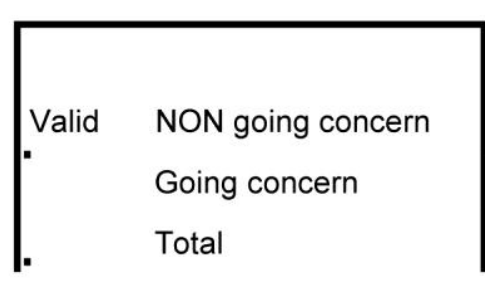
Frequency $\mid$

Sumber: output SPSS, data diolah 2018

Berdasarkan Tabel 4.2, 4.3, 4.4, 4.5 dapat dijelaskan sebagai berikut ini:

a. Kepemilikan institusional memiliki nilai rata-rata (mean) sebesar 73,4 dengan standar deviasi 12,08 maka nilai rata-rata lebih besar dari standar deviasinya sehingga mengindikasikan kualitas data dari variabel ini baik. Hal tersebut dikarenakan standar deviasi adalah pencerminan penyimpangan, sehingga penyebaran data menunjukkan hasil yang normal. Berdasarkan hasil olahan statistik deskriptif di atas kepemilikan institusional memiliki nilai minimum 36,77 dan nilai maksimum sebesar 89,26 .

b. Komisaris independen diukur dengan menggunakan jumlah komisaris independen dibanding total jumlah komisaris dalam perusahaan. Nilai rata-rata yang didapat adalah 0,42 dan standar deviasi atau tingkat penyebaran sebesar 0,10. Dengan begitu nilai rata-rata lebih besar dari standar deviasinya sehingga mengindikasikan kualitas data dari variabel ini baik. Hal tersebut dikarenakan standar deviasi adalah pencerminan penyimpangan, sehingga penyebaran data menunjukkan hasil yang normal. Nilai rata-rata di atas menunjukkan bahwa mayoritas perusahaan men- \begin{tabular}{r|r|r|}
\multicolumn{2}{|c|}{ Opini audit } \\
Percent & Valid Percent & Cumulative Percent \\
73,3 & 73,3 & 73,3 \\
26,7 & 26,7 & 100,0 \\
100,0 & 100,0 &
\end{tabular} taati peraturan yang dibuat oleh OJK yang mewajibkan jumlah komisaris independen paling sedikit tiga puluh persen dari total seluruh anggota dewan komisaris. Namun demikian nilai minimum sebesar $25 \%$ menunjukkan ada perusahaan sampel yang jumlah komisaris independennya kurang dari batas yang ditentukan oleh peraturan OJK, hal ini tentu sangat tidak baik bagi perusahaan mengingat pentingnya peran dewan komisaris untuk mengawasi jalannya perusahaan. Sedangkan nilai minimum pada variabel komisaris independen adalah 0,25 dan nilai maksimumnya 0,75 .

c. Komite audit diproksikan dengan anggota komite yang memiliki latar belakang pendidikan akuntansi, memiliki sertifikat di bidang akuntansi, atau pengalaman kerja di bidang akuntansi dan keuangan. Mendapatkan nilai rata-rata sebesar 75,08 dan standar deviasi atau tingkat penyebaran 23,87 dengan nilai minimum 20,00 dan maksimum 100,00. Nilai minimum sebesar 20,00 menunjukkan ada perusahaan sampel yang tidak peduli dengan komposisi anggota komite auditnya, sedangkan nilai maksimum 100 menunjukkan keseriusan perusahaan sampel dalam 
menjalankan fungsi komite audit dengan menempatkan anggota yang memiliki latar belakang di bidang akuntansi. Nilai rata-rata lebih besar dari standar deviasinya sehingga mengindikasikan kualitas data dari variabel ini baik. Hal tersebut dikarenakan standar deviasi adalah pencerminan penyimpangan, sehingga penyebaran data menunjukkan hasil yang normal.

d. Audit client tenure adalah masa perikatan KAP dengan perusahaan diukur dengan skala interval tahun perikatan, mendapatkan nilai ratarata sebesar 3,24 dengan standar deviasi 1,59 variabel ini memiliki rata-rata yang lebih besar dari standar deviasinya sehingga mengindikasikan kualitas data dari variabel ini baik. Hal tersebut dikarenakan standar deviasi adalah pencerminan penyimpangan, sehingga penyebaran data menunjukkan hasil yang normal. Sedangkan nilai minimum 1,00 dan maksimum sebanyak 6,00 artinya dari 75 perusahaan sampel paling sedikit melakukan masa perikatan dengan KAP adalah selama 1 tahun dan paling lama selama 6 tahun.

e. Opinion shopping diukur menggunakan variabel dummy dengan kode 1 untuk perusahaan yang melakukan pergantian auditor dan kode 0 untuk perusahaan yang tidak mengganti auditor. Berdasarkan tabel frekuensi menunjukkan adanya 42 perusahaan (56\%) yang tidak mengganti auditor, sedangkan 33 perusahaan (44\%) melakukan pergantian auditor.

f. Kualitias audit untuk perusahaan yang menggunakan jasa KAP big four diberi kode 1 dan yang menggunakan KAP non big four diberi kode 0. Berdasarkan tabel frekuensi bisa dilihat bahwa dari 75 perusahaan sampel ada 26 perusahaan $(34,7 \%)$ menggunakan jasa KAP big four, sedangkan 49 perusahaan $(65,3 \%)$ tidak menggunakan jasa KAP big four.

g. Opini audit going concern menggunakan kode 0 untuk perusahaan yang tidak menerima opini audit going concern dan kode 1 untuk perusahaan yang menerima opini audit going concern. Dengan melihat data frekuensi di atas, menunjukkan bahwa terdapat 55 perusahaan $(73,3 \%)$ yang tidak mendapat opini audit going concern dan ada 20 perusahaan $(26,7 \%)$ yang mendapatkan opini audit going concern.

\section{Menilai Keseluruhan Model Fit (Overall Fit Model).}

Digunakan untuk menilai model yang dihipotesiskan sudah fit atau tidak dengan data statistik yang digunakan berdasarkan fungsi yang sesuai yaitu fungsi likelihood.

Tabel 4.6

Overall Model Fit Test

-2LL Block 0 : Beginning Block

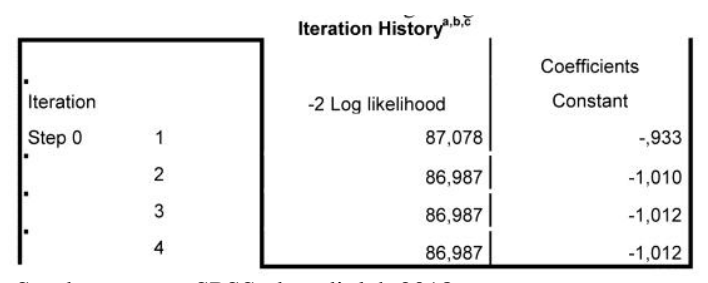

Sumber: output SPSS, data diolah 2018

Berdasarkan output spss 22 diatas menunjukkan bahwa -2LL Block Number $=0$, untuk model hanya memasukkan konstanta tanpa adanya variabel independen dan iperoleh nilai -2LL yaitu 86,987. Langkah selanjutnya untuk menentukan overall model fit test adalah 
dengan melihat nilai -2LL Block Number $=1$ pada Tabel 4.7 yaitu pada saat dimasukan variabel independen pada model tersebut.
Pengujian dilakukan dengan membandingkan nilai antara -2LL Block Number $=0$ dengan $-2 \mathrm{LL}$ Block Number $=1$.

Tabel 4.7.

Overall Model Fit Test

-2LL Block 1 : Method=Enter

Iteration History ${ }^{a, b, c, d}$

\begin{tabular}{|c|c|c|c|c|c|c|c|c|c|}
\hline & & $-2 \log$ & & & & efficients & & & \\
\hline Iteration & & likelihood & Constant & INST & IND & KOM & OS & REPKAP & TEN \\
\hline Step 1 & 1 & 56,605 & $-4,109$ & ,026 & 6,194 & ,000 & 230 &,- 936 &,- 360 \\
\hline & 2 & 47,322 & $-5,580$ & ,038 & 9,268 &,- 002 & ,322 & $-1,869$ &,- 623 \\
\hline & 3 & 43,919 & $-6,107$ & ,046 & 11,319 &,- 008 & ,370 & $-3,094$ &,- 837 \\
\hline & 4 & 42,828 & $-6,195$ & ,051 & 12,380 &,- 014 & ,395 & $-4,436$ &,- 954 \\
\hline & 5 & 42,523 & $-6,184$ & ,053 & 12,703 &,- 017 & ,408 & $-5,627$ &,- 990 \\
\hline & 6 & 42,425 & $-6,183$ & ,053 & 12,746 &,- 017 & ,410 & $-6,672$ &,- 994 \\
\hline & 7 & 42,390 & $-6,183$ & ,053 & 12,749 &,- 017 & ,411 & $-7,683$ &,- 995 \\
\hline & 8 & 42,378 & $-6,183$ & ,053 & 12,749 &,- 017 & ,411 & $-8,686$ &,- 995 \\
\hline & 9 & 42,373 & $-6,183$ & ,053 & 12,749 &,- 017 & ,411 & $-9,688$ &,- 995 \\
\hline & 10 & 42,371 & $-6,183$ & ,053 & 12,749 &,- 017 & ,411 & $-10,688$ &,- 995 \\
\hline & 11 & 42,371 & $-6,183$ & ,053 & 12,749 &,- 017 & ,411 & $-11,688$ &,- 995 \\
\hline & 12 & 42,370 & $-6,183$ & ,053 & 12,749 &,- 017 & ,411 & $-12,688$ &,- 995 \\
\hline & 13 & 42,370 & $-6,183$ & ,053 & 12,749 &,- 017 & ,411 & $-13,688$ &,- 995 \\
\hline & 14 & 42,370 & $-6,183$ & ,053 & 12,749 &,- 017 & ,411 & $-14,688$ &,- 995 \\
\hline & 15 & 42,370 & $-6,183$ & ,053 & 12,749 &,- 017 & ,411 & $-15,688$ &,- 995 \\
\hline & 16 & 42,370 & $-6,183$ & ,053 & 12,749 &,- 017 & ,411 & $-16,688$ &,- 995 \\
\hline & 17 & 42,370 & $-6,183$ & ,053 & 12,749 &,- 017 & ,411 & $-17,688$ &,- 995 \\
\hline & 18 & 42,370 & $-6,183$ & ,053 & 12,749 &,- 017 & ,411 & $-18,688$ &,- 995 \\
\hline & 19 & 42,370 & $-6,183$ & ,053 & 12,749 &,- 017 & ,411 & $-19,688$ &,- 995 \\
\hline & 20 & 42,370 & $-6,183$ & ,053 & 12,749 &,- 017 & ,411 & $-20,688$ &,- 995 \\
\hline
\end{tabular}

Sumber: output SPSS, data diolah 2018

Dari tabel Overall Model Fit Test diatas menunjukan adanya penurunan angka di mana pada -2LL Block Number $=0$ mempunyai nilai sebesar 86,987 dan Block Number $=1$ mempunyai nilai 42,370. Penurunan yang terjadi senilai 44,617. Adanya penurunan pada model ini menunjukkan bahwa model yang dihipotesiskan sudah fit atau sesuai dengan data.
3. Menilai Kelayakan Model Regresi

Tabel 4.8

Penilaian Kelayakan Model Regresi

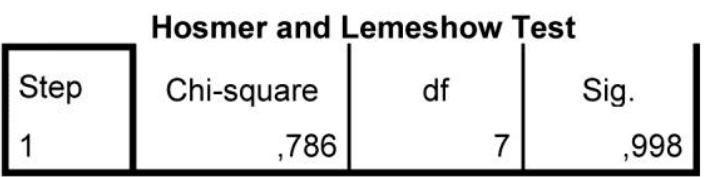

Sumber: output SPSS, data diolah 2018

Untuk kelayakan model regresi dinilai dengan Hosmer and Lemeshow Goodness of Fit Test. Hosmer and 
Lemeshow Goodness of Fit Test menguji hipotesis nol bahwa data empiris cocok atau sesuai model (tidak adanya perbedaan model dengan data sehingga model dapat dikatakan fit). Berdasarkan Tabel 4.8 dapat dijelaskan bahwa nilai statistik Hosmer and Lemeshow Goodness of Fit Test adalah 0,786 dengan probabilitas signifikansi 0,998 yang nilainya jauh di atas 0,05 . Dengan demikian disimpulkan bahwa model mampu memprediksi nilai observasinya atau dapat dikatakan model bisa diterima karena sesuai dengan data observasinya.

\section{Koefisien Determinasi (Menguji Nagelkerke's R Square Test) \\ Tabel 4.9 \\ Koefisien Determinasi

\begin{tabular}{|l|r|c|c|}
\hline & & \multicolumn{1}{|c|}{ Model Summary } \\
Step & -2 Log likelihood & Square & Square \\
1 & $42,370^{\mathrm{a}}$ &, 448 &, 653
\end{tabular}

Sumber: output SPSS, data diolah 2018
Besarnya suatu nilai koefisien determinasi pada model regresi logistik ditunjukkan dengan nilai Nagelkerke's $R$ Square. Untuk menguji koefisien determinasi dengan menggunakan nilai Nagelkerke's $R$ Square untuk mengetahui besarnya nilai variabilitas variabel bebas (independen) mampu memperjelas variabel terikat (dependen). Berdasarkan hasil pengujian yang ditunjukkan pada Tabel 4.9, nilai Nagelkerke's $R$ Square adalah sebesar 0,653 yang berarti variabilitas variabel independen yang terdiri dari kepemilikan institusional, dewan komisaris independen, komite audit, opinion shopping, kualitas audit, dan audit client tenure dapat menjelaskan variabel terikat (dependen) yaitu opini audit going concern sebesar 65,3\%, sedangkan sisanya sebesar $34,7 \%$ dijelaskan oleh variabel lain yang tidak diterangkan dalam penelitian ini.

\section{Tabel Klasifikasi}

Tabel 4.10

Tabel Klasifikasi

Classification Table ${ }^{a}$

\begin{tabular}{|c|c|c|c|c|c|}
\hline & & & \multicolumn{3}{|c|}{ Predicted } \\
\hline & & & \multicolumn{2}{|c|}{ Opini aufit } & \\
\hline \multicolumn{3}{|c|}{ Observed } & $\begin{array}{l}\text { NON going } \\
\text { concern }\end{array}$ & $\begin{array}{l}\text { Going } \\
\text { concern }\end{array}$ & $\begin{array}{c}\text { Percentage } \\
\text { Correct }\end{array}$ \\
\hline \multirow[t]{3}{*}{ Step 1} & Opini audit & NON going concern & 52 & 3 & 94,5 \\
\hline & 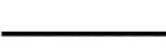 & Going concern & 7 & 13 & 65,0 \\
\hline & Overall Perc & age & & & 86,7 \\
\hline
\end{tabular}

a. The cut value is, 500

Sumber: output SPSS, data diolah 2018

Berdasarkan tabel di atas menjelaskan kekuatan prediksi dari model regresi untuk memprediksi kemungkinan perusahaan menerima opini audit going concern adalah sebesar 65,0 persen. Hal ini menunjukkan bahwa dengan menggunakan model regresi tersebut, ada sebanyak 13 perusahaan $(65 \%)$ yang diprediksi akan menerima opini audit going concern dari total 20 perusahaan yang memperoleh opini audit going concern. 
Kekuatan prediksi dari model regresi untuk memprediksi kemungkinan perusahaan memperoleh opini audit non going concern adalah 94,5\%. Hal ini berarti dengan model regresi tersebut, terdapat sebanyak 52 perusahaan $(94,5 \%)$ yang diprediksi akan menerima opini audit non going concern dari total 55 perusahaan yang menerima opini audit non going concern.
Selanjutnya dapat disimpulkan bahwa kekuatan prediksi dari model regresi sebesar $86,7 \%$.

6. Model Regresi Logistik yang terbentuk dan pengujian hipotesis

Model regresi dapat dibentuk dengan melihat pada nilai estimasi parameter dalam Variables in The Equation.

Tabel 4.11

Analisis Regresi Logistik

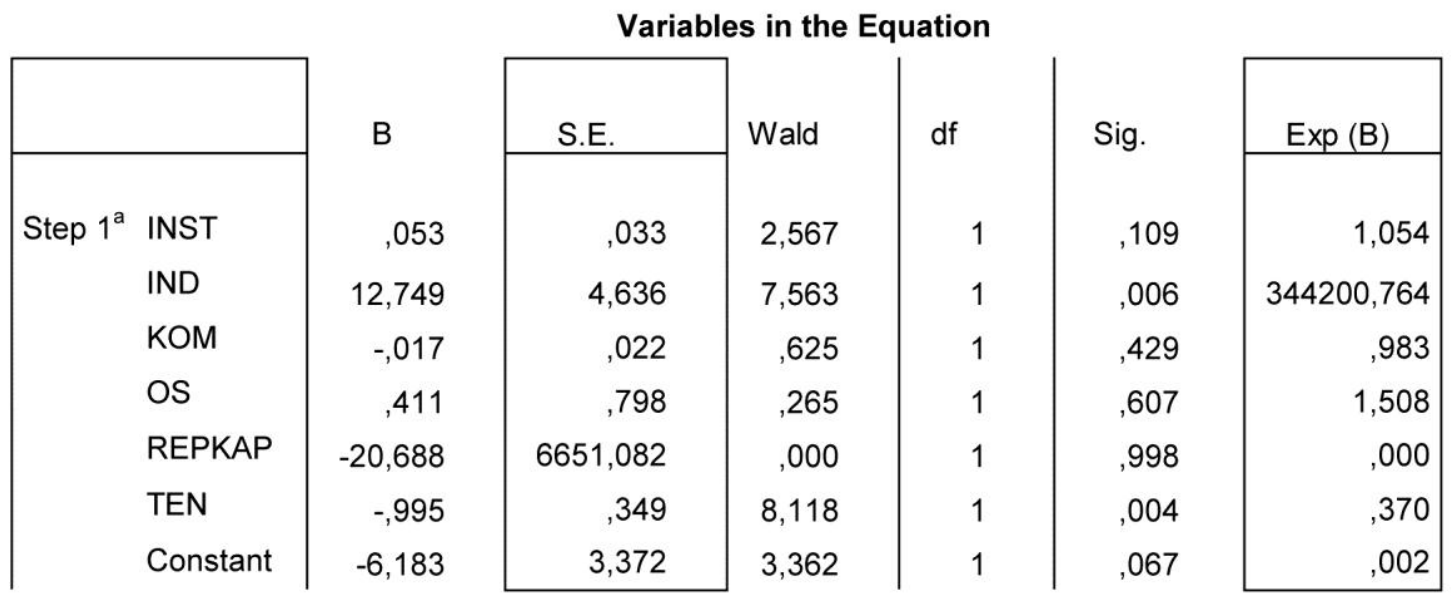

a. Variable(s) entered on step 1: INST, IND, KOM, OS, REPKAP, TEN.

Sumber: output SPSS, data diolah 2018

Pengujian hipotesis dilakukan dengan cara membandingkan tingkat signifikansi (sig) dengan

$$
(\alpha)=5 . \text { B } \quad 4 .
$$

ini:

1) H1: Kepemilikan Institusional diduga berpengaruh terhadap penerimaan opini audit going concern.

Pada hasil pengujian menunjukkan variabel kepemilikan institusional memiliki koefisien regresi
f , 53
f , 9
$\alpha(5)$.

Berdasarkan pada hal tersebut bisa disimpulkan variabel kepemilikan institusional tidak berpengaruh ter- hadap opini audit going concern, maka $\mathrm{H} 1$ ditolak.

2) H2: Komisaris independen diduga berpengaruh terhadap penerimaan opini audit going concern.

Pada hasil pengujian menunjukkan variable komisaris independen memiliki koefisien regresi

f $2,749 \quad \mathrm{f}, 6$ c $\quad \alpha(5)$.

Berdasarkan hal tersebut dapat disimpulkan bahwa variabel komisaris independen berpengaruh terhadap opini audit going concern, maka $\mathrm{H} 2$ diterima.

3) H3: Komite audit diduga berpengaruh terhadap penerimaan opini audit going concern. 
Pada hasil pengujian menunjukkan variabel komite audit memiliki koefisien regresi negatif yaitu sebesar $-0,017$ dengan nilai tingkat signifikansi 0,429 yang lebih besar da $\alpha(5)$.

Berdasarkan pada hal tersebut bisa disimpulkan variabel komite audit tidak berpengaruh terhadap opini audit going concern, maka $\mathrm{H} 3$ ditolak.

4) H4: Opinion Shopping diduga berpengaruh terhadap penerimaan opini audit going concern.

Pada hasil pengujian menunjukkan variabel opinion Shopping memiliki koefisien regresi positif

,4 f, $67 \quad \alpha(5)$.
Berdasarkan hal tersebut dapat disimpulkan bahwa variabel opinion Shopping tidak berpengaruh terhadap opini audit going concern, maka $\mathrm{H} 2$ ditolak.

5) H5: Kualitas audit diduga berpengaruh terhadap penerimaan opini audit going concern.

Pada hasil pengujian menunjukkan variabel kualitas audit memiliki koefisien regresi negatif sebesar -20,688 d f, $998 \quad \alpha(5)$. Berdasarkan pada hal tersebut bisa disimpulkan variabel kualitas audit tidak berpengaruh terhadap opini audit going concern, maka H5 ditolak.

6) H6: Audit Client Tenure diduga berpengaruh terhadap penerimaan opini audit going concern. Pada hasil pengujian menunjukkan variabel audit client tenure memiliki koefisien regresi negatif

sebesar-,995 f , 4 c $\alpha(5)$. Berdasarkan hal tersebut dapat disimpulkan bahwa variabel audit client tenure berpengaruh terhadap opini audit going concern, maka H6 diterima.

\section{E. KESIMPULAN DAN SARAN}

\section{Kesimpulan}

Berdasarkan hasil analisis data dan pembahasan yang telah dilakukan, maka dapat disimpulkan bahwa :

a. Kepemilikan institusional tidak berpengaruh terhadap opini audit going concern pada perushaan infrastuktur, utilitas, dan transportasi yang terdaftar di Bursa Efek Indonesia tahun 2013-2017 dengan nilai signifikan sebesar 0,109 > 0,05.

b. Komisaris independen berpengaruh terhadap opini audit going concern pada perushaan infrastuktur, utilitas, dan transportasi yang terdaftar di Bursa Efek Indonesia tahun 2013

- 2017 dengan nilai signifikan sebesar $0,006<0,05$. Hal ini menunjukkan bahwa semakin tinggi tingkat komisaris independen maka semakin kecil perusahaan mendapat opini audit going concern.

c. Komite audit tidak berpengaruh terhadap opini audit going concern pada perushaan infrastuktur, utilitas, dan transportasi yang terdaftar di Bursa Efek Indonesia tahun 20132017 dengan nilai signifikan sebesar $0,429>0,05$.

d. Opinion shopping tidak berpengaruh terhadap opini audit going concern pada perushaan infrastuktur, utilitas, dan transportasi yang terdaftar di Bursa Efek Indonesia tahun 20132017 dengan nilai signifikan sebesar $0,607>0,05$. Hal ini menunjukkan bahwa tidak ada pengaruh opinion shopping terhadap opini audit going concern.

e. Kualitas audit tidak berpengaruh terhadap opini audit going concern pada perushaan infrastuktur, utilitas, dan transportasi yang terdaftar di Bursa Efek Indonesia tahun 2013- 
2017 dengan nilai signifikan sebesar 0,998 .

f. Audit client tenure berpengaruh terhadap opini audit going concern pada perushaan infrastuktur, utilitas, dan transportasi yang terdaftar di Bursa Efek Indonesia tahun 20132017 dengan nilai signifikan sebesar $0,004<0,05$. Hal ini menunjukkan bahwa semakin lama perikatan KAP dengan klien maka independensi auditor akan berkurang dengan begitu semakin kecil perusahaan akan menerima opini audit going concern.

\section{Saran}

Berdasarkan Kesimpulan Dari Penelitian Ini, Maka Bisa Dibderikan Saran-Saran Sebagai berikut Yaitu:

1. Disarankan bagi perusahaan agar lebih memperhatikan mengenai aspek-aspek yang dapat mengganggu kelangsungan hidup perusahaan. Pentingnya memahami regulasi yang dibuat agar bisa lebih dari sekedar mematuhi peraturan namun dijalankan dan dimaksimalkan benar-benar untuk kebaikan bagi semua pemangku kepentingan.

2. Bagi calon investor ataupun investor lebih baik dalam menilai laporan keuangan perusahaan khususnya yang barkaitan dengan kelangsungan hidup perusahaan, karena laporan keuangan yang baik akan lebih kon- sisten dalam memberikan keuntungan. Tidak lupa mengenai tata kelola perusahaan harus sesuai dan memenuhi peraturan yang diberlaku.

3. Untuk peneliti selanjutnya disarankan memperpanjang periode pengamatan pada penelitian dan memperluas penelitian dengan menambahkan sampel penelitian yaitu seluruh perusahaan yang terdaftar di Bursa Efek Indonesia (BEI) agar hasil yang didapatkan bisa digeneralisasi dan akan lebih menggambarkan kondisi sesungguhnya dalam jangka waktu yang panjang.

4. Dari hasil uji koefisien determinasi (Nagelkerke $R$ Square) menunjukkan nilai sebesar $65,3 \%$ sedangkan sisanya sebesar $34,7 \%$ dijelaskan oleh variabel lain yang tidak diterangkan dalam penelitian ini yang mampu mempengaruhi opini audit going concern. Sehingga peneliti selanjutnya dapat menambahkan beberapa variabel independen lain.

5. Diharapkan peneliti selanjutnya menambah variabel lain seperti: analisis kebangkrutan (financial distress) atau mengganti proksi kualitas audit diukur dengan auditor industi spesialis, menambahkan variabel kepemilikan manajerial, variabel disclousure, dan ukuran perusahaan.

\section{DAFTAR PUSTAKA}

A, E. 22 "Analisis Hubungan Antara Kondisi Keuangan Perusahaan dengan Penerimaan Opini Audit Going Concern". Skripsi. Semarang: Fakultas Ekonomika dan Bisnis, Universitas Diponegoro.

Aj, ESRj. 23. "AP Corporate Governance Terhadap Kemungkinan Pemberian Opini Audit Going Concern Oleh Auditor Independen (Studi Empiris pada Perusahaan Manufaktur Yang Terdaftar di BEI Tahun 2009 - 2)". Diponegoro Journal of Accountin $g$ Vol. 2 No. 2. 2013 hal : 1 - 10.

Aj, GN G.A.M A jP. 26. "PO Going Concern dan APA". E-Jurnal Akuntansi Universitas Udayana Vol. 16 No. 3.September 2016 hal : 1716 - 1743. 
v, E N. 25. "PM Corporate Governance Terhadap Pemberian Opini Audit Going Concern (Studi Empiris pada Perusahaan Manufaktur yang Terdaftar di Bursa Efek Indonesia Tahun 2011 - 23)". JRAMB Vol. 1 No. 1. Mei 2015.

f, R v BS. 25. "P, A, Perusahaan Terhadap Penerimaan Opini Audit Going Concern". Jurnal Ilmu \& Riset Akuntansi Vol 4 No. 8. 2015.

Elv, .27. "P, , OA Sebelumnya, Ukuran Perusahaan, Kualitas Audit dan Opinion Shopping Terhadap Opini Audit pada Perusahaan Manufaktur yang Mengalami Financial Distress di BEI (2013 - 25)". Jurnal. Universitas Maritim Raja Ali Haji Tanjungpinang.

Ghozali, Imam. 2016. Aplikasi Analisis Multivariate dengan Program IBM SPSS 23. Semarang : Badan Penerbit Universitas Diponegoro.

Krissindiastuti, Monica dan Ni Ketut Rasmini. 26. "Faktor-Faktor yang Mempengaruhi Opini Audit Going Concern. E-Jurnal Akuntansi Universitas Udayana Vol.14 Januari 2016 hal : $451-481$.

,N P Ev N S W. 27. "P Opinion Shopping, Disclosure, Reputasi KAP pada Opini Audit Going Concern". E-Jurnal Akuntansi Universitas Udayana Vol.18 No. 3. Maret 2017 hal : $2290-2317$.

M, V. 27. "P A, f, Opinion Shopping, Dan Pertumbuhan Perusahaan Terhadap Penerimaan Opini Audit Going Concern Pada Perusahaan Manufaktur (Yang Terdaftar di Bursa Efek Indonesia 2011 - 2 5)". JOM Fekon Universitas Riau Vol. 4 No. 1.Februari 2017 hal : $1613-1627$.

N, N. . 2 6. "Pengaruh Struktur Kepemilikan Dan Likuidtas Terhadap Penerimaan Opini Audit Modifikasi Going Concern (Studi Kasus Pada Perusahaan Manufaktur Yang Terdaftar Di Bursa Efek Indonesia Periode 2010-2 5)". e-Proceeding of Management Vol. 3 No. 3.Desember 2016 hal : 3266 - 3273.

N, A B H j. 2 3. "P Ef v A Financial Distress". Diponegoro Journal of Accounting Vol. 2 No. 2. 2013 hal : $1-10$.

N, E Ev M. 2 5. "P A, Opinion Shopping, Leverage dan Pertumbuhan Perusahaan Terhadap Penerimaan Opini Audit Going Concern Pada Perusahaan Perbankan Dan Pembiayaan Yang Go Public B Ef". Jurnal Ilmiah Bisnis dan Ekonomi STIE ASIA Vol. 9 No.1.Februari 2015. Hal: 37 - 43.

Praptitorini, Mirna Dyah dan Januarti. 2011. "Analisis Pengaruh Kualitas Audit, Debt Default Dan Opinion Shopping Terhadap Penerimaan Opini Going Concern. Jurnal Akuntansi dan Keuangan Indonesia Vol. 8 No. 1.Juni 2011. Hal : 78 - 93.

Purba, Marisi. 2016. Asumsi Going Concern. Yogyakarta : Ekuilibria.

R, S f S. 2 5. "P , , A, Institusional Terhadap Opini Audit Asumsi Going Concern". Jom FEKON Faculty of Economics Riau University Vol. 2 No.2.Oktober 2015.

S , N A S . . 2 5. "A F -Faktor yang Mempengaruhi Kecenderungan Penerimaan Opini Audit Going Concern Pada perusahaan Manufaktur (Studi Empiris pada Perusahaan Manufaktur yang Terdaftar di BEI Periode 2009 - 2 3)”. e-Journal S1 Akuntansi Universitas Pendidikan Ganesha. Vol. 3 No. 1. 2015. 
Sekaran, Uma. 2011. Metodologi Penelitian Untuk Bisnis. Edisi 4. Buku 1. Terjemahan Kwan Men Yon dari Research Methods For Business. Jakarta : Salemba Empat.

Sekaran, Uma. 2006. Metodologi Penelitian Untuk Bisnis. Edisi 4. Buku 2. Terjemahan Kwan Men Yon dari Research Methods For Business. Jakarta : Salemba Empat.

S, A Y. 2 6. "P Audit Tenure, Debt Default, Reputasi Auditor, Ukuran Perusahaan, Proporsi Dewan Komisaris Independen, Dan Kepemilikan Manajerial Terhadap Opini Audit Going Concern (studi Empiris Pada Perusahaan di Jakarta Islamic Index Tahun 2013 - 2 5)". Skripsi. Surakarta: Fakultas Ekonimi Dan Bisnis, Institute Agama Islam Negeri Surakarta.

Sj, M A . 24 "Pengaruh Opinion Shopping Terhadap Going Concern Oppinion Pada Perusahaan yang Mengalami Financial Distress". Skripsi. Semarang: Fakultas Ekonomika dan Bisnis, Universitas Diponegoro.

Tandungan, Debby dan M M . 2 6. "Pengaruh Komite Audit, Ukuran Perusahaan, Audit Tenure, Dan Reputasi Kap Terhadap Opini Audit Going Concern”. E-Jurnal Akuntansi Universitas Udayana Vol.16 No. 1.Juli 2016 hal : 45 - 71.

z, R A. 2 6. "P uh Kepemilikan Manajerial, Kepemilikan Institusional, Free Cash Flow, dan Profitabilitas Terhadap Kebijakan Deviden Pada Perusahaan Manufaktur Go Public Yang Terdaftar Di BEI (periode 2010 - 2 3)". Jurnal Akuntansi \& Keuangan Vol.6 No. 2.September 2015.

W, A.A.A P . 2 . "O A G C c F -Faktor yang mempengaruhi: SP M f B Ef". Tesis Dipublikasikan. Universitas Udayana Denpasar.

Y, A A S M . 2 2. "F -Faktor Non Keuangan Yang Mempengaruhi Dikeluarkannya Opini Going Concern". Diponegoro Journal of Accounting Vol.1 Hal 1 - 14.

Y, S c N v R . 2 7. “ P an Opini Audit Going C c P P S S P R E ”. Jurnal Kajian Akuntansi Lembaga Penelitian Universitas Swadaya Gunung Jati. Vol.1 No. 1. Juni 2017.www.idx.co.id 


\section{LAMPIRAN}

Lampiran 1

Daftar perusahaan sampel

\begin{tabular}{|c|l|l|}
\hline No. & \multicolumn{1}{|c|}{ Kode Saham } & \multicolumn{1}{c|}{ Nama Perusahaan } \\
\hline 1 & APOL & Arpeni Pratama Ocean Line Tbk \\
\hline 2 & BBRM & Pelayaran Nasional Bina Buana Raya Tbk \\
\hline 3 & EXCL & PT XL Axiata Tbk \\
\hline 4 & FREN & Smartfren Telecom Tbk \\
\hline 5 & GIAA & Garuda Indonesia (Persero) Tbk \\
\hline 6 & INDX & Tanah Laut Tbk \\
\hline 7 & INDY & Indika Energy Tbk \\
\hline 8 & ISAT & PT Indosat Tbk \\
\hline 9 & LAPD & Leyand International Tbk \\
\hline 10 & MBSS & Mitrabahtera Segara Sejati Tbk \\
\hline 11 & SAFE & Steady Safe Tbk \\
\hline 12 & SUPR & Solusi Tunas Pratama Tbk \\
\hline 13 & TAXI & Express Transindo Utama Tbk \\
\hline 14 & WEHA & WT WEHA Transportasi Indonesia Tbk \\
\hline 15 & Wintermar Offshore Marine Tbk \\
\hline
\end{tabular}

Sumber: Bursa Efek Indonesia, data diolah 2018 
Lampiran 2

Nilai Setiap Variabel

Tahun 2013

\begin{tabular}{|c|l|r|r|r|r|r|r|r|}
\hline NO & Perusahaan & OA & \multicolumn{1}{c|}{ INST } & \multicolumn{1}{c|}{ IND } & KOM & OS & REPKAP & TEN \\
\hline 1 & APOL & 1,00 & 83,30 &, 50 & 66,00 & 1,00 &, 00 & 1,00 \\
\hline 2 & BBRM &, 00 & 74,89 &, 33 & 100,00 & 1,00 &, 00 & 2,00 \\
\hline 3 & EXCL &, 00 & 66,48 &, 33 & 100,00 & 1,00 & 1,00 & 2,00 \\
\hline 4 & FREN & 1,00 & 83,54 &, 60 & 66,00 &, 00 &, 00 & 2,00 \\
\hline 5 & GIAA &, 00 & 82,07 &, 50 & 25,00 & 1,00 & 1,00 & 2,00 \\
\hline 6 & INDX &, 00 & 86,44 &, 33 & 66,00 &, 00 &, 00 & 2,00 \\
\hline 7 & INDY &, 00 & 63,47 &, 33 & 33,00 &, 00 & 1,00 & 2,00 \\
\hline 8 & ISAT &, 00 & 84,79 &, 40 & 20,00 &, 00 & 1,00 & 2,00 \\
\hline 9 & LAPD &, 00 & 63,02 &, 50 & 100,00 &, 00 &, 00 & 2,00 \\
\hline 10 & MBSS &, 00 & 76,68 &, 37 & 100,00 & 1,00 & 1,00 & 2,00 \\
\hline 11 & SAFE & 1,00 & 83,84 &, 50 & 100,00 &, 00 &, 00 & 2,00 \\
\hline 12 & SUPR &, 00 & 79,06 &, 40 & 75,00 &, 00 &, 00 & 2,00 \\
\hline 13 & TAXI &, 00 & 51,00 &, 40 & 66,00 &, 00 & 1,00 & 2,00 \\
\hline 14 & WEHA &, 00 & 72,61 &, 25 & 66,00 &, 00 &, 00 & 2,00 \\
\hline 15 & WINS &, 00 & 67,47 &, 33 & 100,00 & 1,00 &, 00 & 2,00 \\
\hline
\end{tabular}

Tahun 2014

\begin{tabular}{|c|l|r|r|r|r|r|r|r|}
\hline NO & Perusahaan & \multicolumn{1}{c|}{ OA } & \multicolumn{1}{c|}{ INST } & \multicolumn{1}{c|}{ IND } & KOM & \multicolumn{1}{c|}{ OS } & REPKAP & TEN \\
\hline 1 & APOL & 1,00 & 83,30 &, 33 & 66,00 &, 00 &, 00 & 2,00 \\
\hline 2 & BBRM &, 00 & 82,37 &, 40 & 100,00 & 1,00 &, 00 & 1,00 \\
\hline 3 & EXCL &, 00 & 66,48 &, 33 & 100,00 &, 00 & 1,00 & 3,00 \\
\hline 4 & FREN & 1,00 & 81,72 &, 60 & 66,00 &, 00 &, 00 & 3,00 \\
\hline 5 & GIAA &, 00 & 86,45 &, 28 & 33,00 &, 00 & 1,00 & 3,00 \\
\hline 6 & INDX &, 00 & 86,44 &, 50 & 66,00 & 1,00 &, 00 & 3,00 \\
\hline 7 & INDY &, 00 & 63,47 &, 33 & 33,00 &, 00 & 1,00 & 3,00 \\
\hline 8 & ISAT &, 00 & 79,29 &, 42 & 25,00 & 1,00 & 1,00 & 3,00 \\
\hline 9 & LAPD & 1,00 & 61,96 &, 50 & 100,00 &, 00 &, 00 & 3,00 \\
\hline 10 & MBSS &, 00 & 76,68 &, 57 & 100,00 &, 00 & 1,00 & 3,00 \\
\hline 11 & SAFE & 1,00 & 83,84 &, 50 & 66,00 & 1,00 &, 00 & 1,00 \\
\hline 12 & SUPR &, 00 & 79,06 &, 40 & 75,00 &, 00 &, 00 & 3,00 \\
\hline 13 & TAXI &, 00 & 51,00 &, 40 & 66,00 & 1,00 &, 00 & 1,00 \\
\hline 14 & WEHA &, 00 & 66,48 &, 33 & 66,00 &, 00 &, 00 & 3,00 \\
\hline 15 & WINS &, 00 & 60,80 &, 33 & 100,00 &, 00 &, 00 & 3,00 \\
\hline
\end{tabular}


Tahun 2015

\begin{tabular}{|c|l|r|r|r|r|r|r|r|}
\hline NO & Perusahaan & \multicolumn{1}{l|}{ OA } & \multicolumn{1}{c|}{ INST } & \multicolumn{1}{c|}{ IND } & \multicolumn{1}{c|}{ KOM } & \multicolumn{1}{c|}{ OS } & REPKAP & TEN \\
\hline 1 & APOL & 1,00 & 83,30 &, 50 & 66,00 &, 00 &, 00 & 3,00 \\
\hline 2 & BBRM &, 00 & 82,37 &, 40 & 100,00 &, 00 &, 00 & 2,00 \\
\hline 3 & EXCL &, 00 & 66,43 &, 28 & 100,00 &, 00 & 1,00 & 4,00 \\
\hline 4 & FREN & 1,00 & 88,08 &, 60 & 66,00 & 1,00 &, 00 & 4,00 \\
\hline 5 & GIAA &, 00 & 85,13 &, 28 & 33,00 &, 00 & 1,00 & 4,00 \\
\hline 6 & INDX &, 00 & 81,46 &, 50 & 66,00 &, 00 &, 00 & 4,00 \\
\hline 7 & INDY &, 00 & 68,69 &, 33 & 33,00 & 1,00 & 1,00 & 4,00 \\
\hline 8 & ISAT &, 00 & 79,29 &, 30 & 50,00 & 1,00 & 1,00 & 1,00 \\
\hline 9 & LAPD & 1,00 & 62,23 &, 50 & 100,00 & 1,00 &, 00 & 1,00 \\
\hline 10 & MBSS &, 00 & 76,68 &, 40 & 100,00 &, 00 & 1,00 & 4,00 \\
\hline 11 & SAFE & 1,00 & 83,84 &, 50 & 66,00 & 1,00 &, 00 & 1,00 \\
\hline 12 & SUPR &, 00 & 68,70 &, 40 & 75,00 & 1,00 &, 00 & 4,00 \\
\hline 13 & TAXI &, 00 & 51,00 &, 50 & 66,00 &, 00 &, 00 & 2,00 \\
\hline 14 & WEHA &, 00 & 61,84 &, 50 & 100,00 & 1,00 &, 00 & 4,00 \\
\hline 15 & WINS &, 00 & 54,45 &, 33 & 100,00 & 1,00 &, 00 & 4,00 \\
\hline
\end{tabular}

Tahun 2016

\begin{tabular}{|c|l|r|r|r|r|r|r|r|}
\hline NO & Perusahaan & \multicolumn{1}{c|}{ OA } & \multicolumn{1}{c|}{ INST } & \multicolumn{1}{c|}{ IND } & \multicolumn{1}{c|}{ KOM } & \multicolumn{1}{c|}{ OS } & REPKAP & TEN \\
\hline 1 & APOL & 1,00 & 83,30 &, 50 & 66,00 & 1,00 &, 00 & 4,00 \\
\hline 2 & BBRM &, 00 & 82,37 &, 40 & 100,00 &, 00 &, 00 & 3,00 \\
\hline 3 & EXCL &, 00 & 66,36 &, 37 & 100,00 & 1,00 & 1,00 & 5,00 \\
\hline 4 & FREN & 1,00 & 88,18 &, 75 & 66,00 & 1,00 &, 00 & 5,00 \\
\hline 5 & GIAA &, 00 & 85,13 &, 28 & 33,00 & 1,00 & 1,00 & 5,00 \\
\hline 6 & INDX &, 00 & 81,46 &, 50 & 66,00 &, 00 &, 00 & 5,00 \\
\hline 7 & INDY &, 00 & 68,69 &, 50 & 100,00 &, 00 & 1,00 & 5,00 \\
\hline 8 & ISAT &, 00 & 79,29 &, 30 & 100,00 & 1,00 & 1,00 & 2,00 \\
\hline 9 & LAPD & 1,00 & 62,32 &, 50 & 100,00 &, 00 &, 00 & 2,00 \\
\hline 10 & MBSS &, 00 & 76,68 &, 40 & 100,00 & 1,00 & 1,00 & 5,00 \\
\hline 11 & SAFE & 1,00 & 89,26 &, 50 & 66,00 & 1,00 &, 00 & 1,00 \\
\hline 12 & SUPR &, 00 & 68,71 &, 40 & 75,00 &, 00 &, 00 & 5,00 \\
\hline 13 & TAXI &, 00 & 51,00 &, 50 & 66,00 &, 00 &, 00 & 3,00 \\
\hline 14 & WEHA &, 00 & 70,36 &, 50 & 66,00 & 1,00 &, 00 & 5,00 \\
\hline 15 & WINS &, 00 & 41,94 &, 50 & 100,00 &, 00 &, 00 & 5,00 \\
\hline
\end{tabular}


Tahun 2017

\begin{tabular}{|c|l|r|r|r|r|r|r|r|}
\hline NO & Perusahaan & \multicolumn{1}{c|}{ OA } & \multicolumn{1}{c|}{ INST } & \multicolumn{1}{c|}{ IND } & \multicolumn{1}{c|}{ KOM } & \multicolumn{1}{c|}{ OS } & REPKAP & TEN \\
\hline 1 & APOL & 1,00 & 83,30 &, 50 & 66,00 &, 00 &, 00 & 5,00 \\
\hline 2 & BBRM & 1,00 & 82,37 &, 40 & 100,00 & 1,00 &, 00 & 4,00 \\
\hline 3 & EXCL &, 00 & 66,36 &, 40 & 100,00 &, 00 & 1,00 & 6,00 \\
\hline 4 & FREN &, 00 & 88,18 &, 75 & 66,00 &, 00 &, 00 & 6,00 \\
\hline 5 & GIAA &, 00 & 86,15 &, 37 & 66,00 & 1,00 & 1,00 & 6,00 \\
\hline 6 & INDX &, 00 & 81,46 &, 50 & 66,00 & 1,00 &, 00 & 6,00 \\
\hline 7 & INDY &, 00 & 68,44 &, 50 & 100,00 & 1,00 & 1,00 & 6,00 \\
\hline 8 & ISAT &, 00 & 79,29 &, 30 & 66,00 &, 00 & 1,00 & 3,00 \\
\hline 9 & LAPD & 1,00 & 62,23 &, 50 & 100,00 &, 00 &, 00 & 1,00 \\
\hline 10 & MBSS &, 00 & 76,68 &, 40 & 100,00 &, 00 & 1,00 & 6,00 \\
\hline 11 & SAFE & 1,00 & 87,67 &, 50 & 66,00 &, 00 &, 00 & 2,00 \\
\hline 12 & SUPR &, 00 & 68,71 &, 40 & 66,00 &, 00 &, 00 & 6,00 \\
\hline 13 & TAXI & 1,00 & 51,00 &, 33 & 33,00 & 1,00 &, 00 & 1,00 \\
\hline 14 & WEHA &, 00 & 70,36 &, 50 & 66,00 &, 00 &, 00 & 6,00 \\
\hline 15 & WINS &, 00 & 36,77 &, 33 & 100,00 & 1,00 &, 00 & 6,00 \\
\hline
\end{tabular}


Lampiran 3

Hasil Output Dengan Spss

Descriptives

\section{Descriptive Statistics}

\begin{tabular}{|l|}
\hline \\
kepemilikan institusional \\
komisaris independen \\
komite audit \\
audit client tenure \\
Valid N (listwise)
\end{tabular}

\begin{tabular}{rr|r|r|r|}
$\mathrm{N}$ & Minimum & Maximum & \multicolumn{1}{l|}{ Mean } \\
& & & \\
75 & 36,77 & 89,26 & 73,4068 \\
75 &, 25 &, 75 &, 4292 \\
75 & 20,00 & 100,00 & 75,0800 \\
75 & 1,00 & 6,00 & 3,2400 \\
75 & & &
\end{tabular}

Std. Deviation

23,87397

1,59255

frequency tabel

\section{opinion shopping}

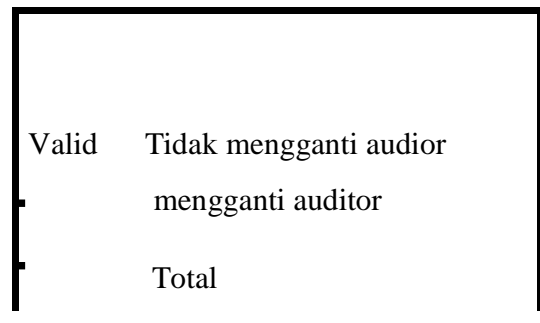

\begin{tabular}{|c|c|}
\hline Frequency & Percent \\
\hline 42 & 56,0 \\
\hline 33 & 44,0 \\
\hline 75 & 100,0 \\
\hline
\end{tabular}

$$
\begin{array}{r}
\text { Valid Percent } \\
56,0 \\
44,0 \\
100,0
\end{array}
$$$$
\text { Cumulative }
$$$$
\text { Percent }
$$

\begin{tabular}{|c|c|c|c|c|c|}
\hline \multirow{4}{*}{-Valid } & & Frequency & Percent & Valid Percent & $\begin{array}{c}\text { Cumulative } \\
\text { Percent }\end{array}$ \\
\hline & Non Big 4 & 49 & 65.3 & 65.3 & 65.3 \\
\hline & Big 4 & 26 & 34,7 & 34,7 & 100,0 \\
\hline & Total & 75 & 100,0 & 100,0 & \\
\hline
\end{tabular}

\section{kualitas audit}

\begin{tabular}{|c|c|c|c|c|c|}
\hline \multirow{4}{*}{ Valid } & & Erequency & Percent & Volid Percent & Cumulative \\
\hline & NON going concern & 55 & 73,3 & 73,3 & 73,3 \\
\hline & Going concern & 20 & 26,7 & 26,7 & 100,0 \\
\hline & Total & 75 & 100,0 & 100,0 & \\
\hline
\end{tabular}

\section{Opini audit}


Block 0: Beginning Block

\begin{tabular}{|c|c|c|c|}
\hline \multicolumn{4}{|c|}{ Iteration History $^{\text {a,b,c }}$} \\
\hline \multirow{2}{*}{\multicolumn{2}{|c|}{ Iteration }} & & Coefficients \\
\hline & & -2 Log likelihood & Constant \\
\hline Step 0 & 1 & 87.078 & -.933 \\
\hline & 2 & 86,987 & $-1,010$ \\
\hline & 3 & 86,987 & $-1,012$ \\
\hline & 4 & 86,987 & $-1,012$ \\
\hline
\end{tabular}

a. Constant is included in the model.

b. Initial -2 Log Likelihood: 86,987

c. Estimation terminated at iteration number 4 because parameter estimates changed by less than ,001.

Classification Table ${ }^{\text {a,b }}$

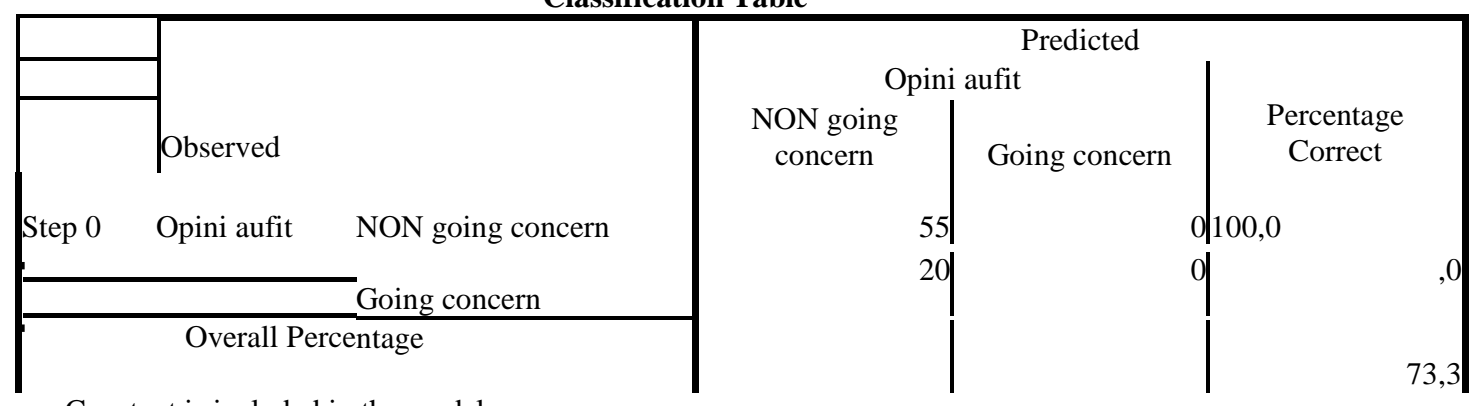

a. Constant is included in the model.

b. The cut value is ,500

\begin{tabular}{|l|r|r|r|}
\hline \multicolumn{3}{|c|}{ Variables not in the Equation } & \\
Step 0 Variables INST & Score & $\mathrm{df}$ & \multicolumn{1}{c|}{ Sig. } \\
IND & 4,774 & 1 &, 029 \\
KOM & 15,232 & 1 &, 000 \\
OS &, 014 & 1 &, 907 \\
REPKAP &, 398 & 1 &, 528 \\
TEN & 14,471 & 1 &, 000 \\
Overall Statistics & 7,690 & 1 &, 006 \\
& 31,750 & 6 &, 000 \\
\hline
\end{tabular}


Block 1: Method = Enter

\begin{tabular}{|c|c|c|c|c|c|c|c|c|c|}
\hline & & & & Iteration & ory $y^{a, b, c, d}$ & & & & \\
\hline & & & & & & Defficients & & & \\
\hline Iteratio & & -2 Log likelihood & Constant & INST & IND & KOM & os & REPKAP & TEN \\
\hline Step 1 & 1 & 56,605 & $-4,109$ &, 026 & 6,194 &, 000 & ,230 &,- 936 &,- 360 \\
\hline & 2 & 47,322 & $-5,580$ &, 038 & 9,268 &,- 002 & ,322 & $-1,869$ &,- 623 \\
\hline & 3 & 43,919 & $-6,107$ & ,046 & 11,319 &,- 008 & ,370 & $-3,094$ &,- 837 \\
\hline & 4 & 42,828 & $-6,195$ & ,051 & 12,380 &,- 014 & ,395 & $-4,436$ &,- 954 \\
\hline & 5 & 42,523 & $-6,184$ & ,053 & 12,703 &,- 017 & ,408 & $-5,627$ &,- 990 \\
\hline & 6 & 42,425 & $-6,183$ & ,053 & 12,746 &,- 017 &, 410 & $-6,672$ &,- 994 \\
\hline & 7 & 42,390 & $-6,183$ & ,053 & 12,749 &,- 017 & ,411 & $-7,683$ &,- 995 \\
\hline & 8 & 42,378 & $-6,183$ &, 053 & 12,749 &,- 017 & ,411 & $-8,686$ &,- 995 \\
\hline & 9 & 42,373 & $-6,183$ &, 053 & 12,749 &,- 017 & ,411 & $-9,688$ &,- 995 \\
\hline & 10 & 42,371 & $-6,183$ & ,053 & 12,749 &,- 017 & ,411 & $-10,688$ &,- 995 \\
\hline & 11 & 42,371 & $-6,183$ & ,053 & 12,749 &,- 017 & ,411 & $-11,688$ &,- 995 \\
\hline & 12 & 42,370 & $-6,183$ & ,053 & 12,749 &,- 017 & ,411 & $-12,688$ &,- 995 \\
\hline & 13 & 42,370 & $-6,183$ & ,053 & 12,749 &,- 017 & ,411 & $-13,688$ &,- 995 \\
\hline & 14 & 42,370 & $-6,183$ &, 053 & 12,749 &,- 017 & 411 & $-14,688$ &,- 995 \\
\hline & 15 & 42,370 & $-6,183$ &, 053 & 12,749 &,- 017 & ,411 & $-15,688$ &,- 995 \\
\hline & 16 & 42,370 & $-6,183$ & ,053 & 12,749 &,- 017 & ,411 & $-16,688$ &,- 995 \\
\hline & 17 & 42,370 & $-6,183$ & ,053 & 12,749 &,- 017 & ,411 & $-17,688$ &,- 995 \\
\hline & 10 & 42,370 & $-6,183$ & ,053 & 12,749 &,- 017 & ,411 & $-18,688$ &,- 995 \\
\hline - & 10 & 42,370 & $-6,183$ & ,053 & 12,749 &,- 017 & ,411 & $-19,688$ &,- 995 \\
\hline 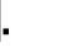 & & 42,370 & $-6,183$ & ,053 & 12,749 &,- 017 & ,411 & $-20,688$ &,- 995 \\
\hline a. Met & d: & & & & & & & & \\
\hline b. Cor & iant & ded in the model. & & & & & & & \\
\hline c. Initi & $-2 \mathrm{~L}$ & lihood: 86,987 & & & & & & & \\
\hline
\end{tabular}

Omnibus Tests of Model Coefficients

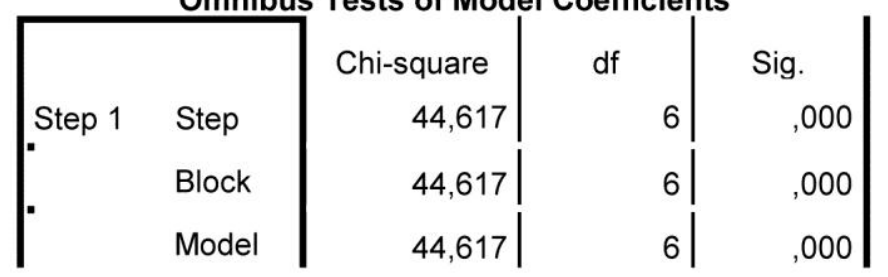

\section{Model Summary}

\begin{tabular}{|l|r|c|c|}
\hline Step & -2 Log likelihood & $\begin{array}{c}\text { Cox \& Snell R } \\
\text { Square }\end{array}$ & \multicolumn{2}{c|}{$\begin{array}{c}\text { Nagelkerke R } \\
\text { Square }\end{array}$} \\
1 & $42,370^{\mathrm{a}}$ &, 448 &, 653
\end{tabular}




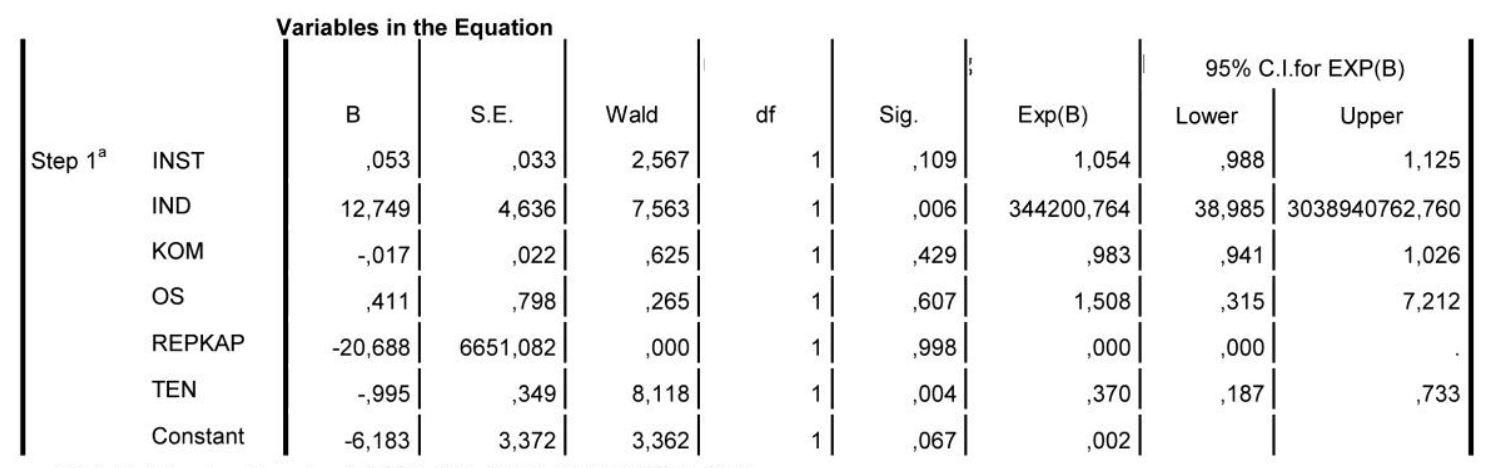

a. Variable(s) entered on step 1: INST, IND, KOM, OS, REPKAP, TEN.

\begin{tabular}{|ll|r|r|r|r|r|r|r|}
\hline Step 1 & Constant & \multicolumn{1}{c}{ Constant } & INST & IND & KOM & OS & REPKAP & \multicolumn{1}{|c|}{ TEN } \\
& INST &,- 000 &,- 619 &,- 467 &,- 514 &,- 226 &, 000 &, 143 \\
& IND & 1,000 &,- 007 &,- 031 &, 056 &, 000 &,- 317 \\
& KOM &,- 467 &,- 007 & 1,000 &,- 068 &, 054 &, 000 &,- 485 \\
& OS &,- 514 &,- 031 &,- 068 & 1,000 &, 109 &, 000 &, 223 \\
& REPKAP &,- 226 &, 056 &, 054 &, 109 & 1,000 &, 000 &, 025 \\
& TEN &, 000 &, 000 &, 000 &, 000 &, 000 & 1,000 &, 000 \\
\hline
\end{tabular}

a. Estimation terminated at iteration number 20 because

maximum iterations has been reached. Final solution cannot

be found.

Classification Table ${ }^{a}$

\begin{tabular}{|c|c|c|c|c|c|}
\hline & & & \multicolumn{3}{|c|}{ Predicted } \\
\hline & & & Opin & aufit & \\
\hline \multirow{4}{*}{ Step 1} & \multicolumn{2}{|l|}{ Observed } & $\begin{array}{l}\text { NON going } \\
\text { concern }\end{array}$ & Going concern & $\begin{array}{c}\text { Percentage } \\
\text { Correct }\end{array}$ \\
\hline & \multirow[t]{2}{*}{ Opini aufit } & NON going concern & 52 & 3 & 94,5 \\
\hline & & Going concern & 7 & 13 & 65,0 \\
\hline & Overall $\mathrm{Pe}$ & ntage & & & 86,7 \\
\hline
\end{tabular}

a. The cut value is, 500

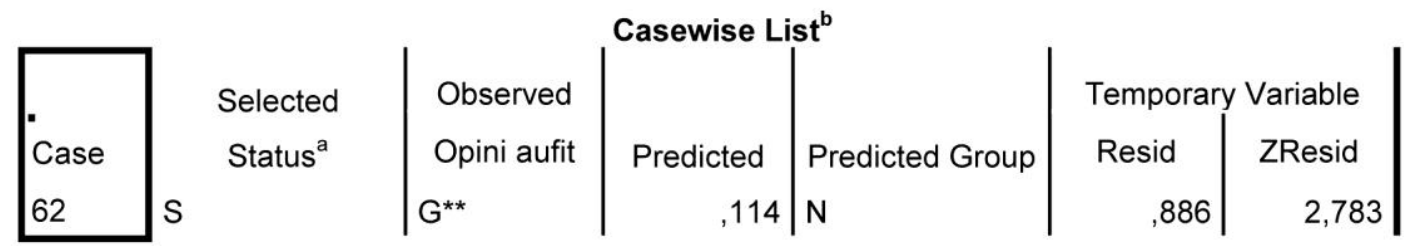

a. $S=$ Selected, $U=$ Unselected cases, and ${ }^{* *}=$ Misclassified cases.

b. Cases with studentized residuals greater than 2,000 are listed. 